\title{
Head injuries in accident and emergency departments. How different are children from adults?
}

Marie Brookes, Robert MacMillan, Stewart Cully, Elaine Anderson, Stan Murray, A David Mendelow, Bryan Jennett

\begin{abstract}
Study objective-The aim of the study was to examine the differences between child and adult patients attending accident and emergency departments after recent head injuries.

Design and setting-A retrospective survey based on existing case records from 23 Scottish accident and emergency departments for 1985 was compared with prospective data from one hospital over 9 months in 1984.
\end{abstract}

Patients - 3838 children under 15 and 4775 adults attended hospital with head injuries during the period analysed.

Main results-Only $9 \%$ of children and $20 \%$ of adults had evidence of brain damage (altered consciousness on arrival, or history of altered consciousness with amnesia on arrival). Scalp lacerations were recorded in $\sim 40 \%$ of both children and adults, more commonly in those without brain damage. Fewer children than adults had a skull $x$ ray; in both age groups $x$ rays were more often done if there was evidence of brain damage, headache, or vomiting, and less often when there was a scalp laceration. Only $11 \%$ of children were admitted compared with $20 \%$ of adults. Admission rates per 100000 population per year were 4011 for children and 1473 for adults (1967 overall); admission rates for brain damage were 290 for children and 341 for adults ( 331 overall).

Conclusions-These are the first population based estimates of frequency of head injuries presenting at accident and emergency departments, analysed by age, gender and cause of injury. They should be of value when planning services for the head injured.

Department of
Accident and Emergency Medicine, Monklands District General Hospital, Airdrie ML6 0JS, United Kingdom M Brookes

Department of Neurosurgery, Institute of

Neurological Sciences, Southern General

Hospital, Glasgow G51 4TF, United Kingdom R MacMillan

$S$ Cully

E Anderson

$S$ Murray

D Mendelow

B Jennett

Correspondence to: Professor Jennett

Accepted for publication September 1989
No routine statistics by diagnosis are published about attenders at accident and emergency departments, to compare with the data on inpatients that are produced annually for England and Wales and for Scotland. Our survey of Scottish hospitals in 1974 disclosed that four to five times as many head injured patients attended as were admitted, ${ }^{1}$ leading us to estimate that about a million new cases of head injury attend hospitals in Britain each year. ${ }^{2}$ Children $(<15$ years) accounted for more than $40^{\circ}$ o of over 3000 head injury attenders in the Scottish survey, ${ }^{1}$ and also in a subsequent review of $\sim 12000$ cases at one English district hospital. ${ }^{3}$ The UK guidelines for the initial management of head injuries published in 1984 apply only to adults, ${ }^{4}$ recognition that the clinical course and risks of complications are expected to be different in children. No report has, however, analysed the differences between head injured children and adults. This paper compares adults and children in more than 3000 attenders collected prospectively in one Scottish district general hospital in 1984; and in more than 5000 from a retrospective survey of 23 Scottish accident and emergency departments in 1985. The 1974 Scottish data were reanalysed to identify children and adults for demographic comparison with the present study, and to discover whether the rates of skull $x$ ray and of admission had changed in the last decade.

\section{Methods}

SURVEY OF SCOTTISH HOSPITALS

The 1974 survey involved all 40 Scottish hospitals which had accident departments. Data were abstracted from existing records as previously described, ${ }^{12}$ for one winter and one summer week chosen at random. One important aim of the 1985 survey was to discover whether the admission rates for attenders had changed differently in the four groups of hospitals previously studied (adult teaching hospitals, children's hospitals, and other hospitals within and beyond 30 miles of the neurosurgical unit). Another aim was to discover whether practice in the West of Scotland (where the Guidelines originated) and in the rest of Scotland was different. Hospitals with very small numbers of head injuries were excluded, and to select the remaining hospitals we used stratified sampling to ensure a balance between different groups and different parts of Scotland. The target numbers of patients required to detect a change in admission rate for each hospital group were calculated, and converted to weeks of sampling needed to yield these numbers, as estimated from the two week samples in 1974. The period of sampling in the 23 hospitals ranged from 2 to 6 weeks, and the number of patients from each hospital from 24 to 607 (table I). The date of the first week of sampling was chosen for each hospital using random number tables.

SURVEY OF MONKLANDS HOSPITAL This district general hospital serves a predominantly urban population of 171000 in Lanarkshire. Data were collected prospectively over a nine month period in 1984 by a succession of 16 senior house officers, all working under the supervision of the accident and emergency consultant (MB), who has a special interest in head injuries. A computerised system for collection of data on all types of case was already in 
Table I Sampling for 23 Scottish hospitals in 1985

\begin{tabular}{|c|c|c|c|}
\hline & & $\begin{array}{l}\text { Weeks } \\
\text { sampled }\end{array}$ & $\mathbf{n}$ \\
\hline 1 & $\begin{array}{l}\text { City Teaching Hospitals: } \\
\text { Royal Infirmary, Glasgow } \\
\text { Western Infirmary, Glasgow } \\
\text { Stobhill General Hospital, Glasgow } \\
\text { Royal Infirmary, Edinburgh } \\
\text { Royal Infirmary, Dundee } \\
\text { Royal Infirmary, Aberdeen }\end{array}$ & $\begin{array}{l}4 \\
4 \\
4 \\
4 \\
4 \\
4\end{array}$ & $\begin{array}{l}607 \\
254 \\
231 \\
528 \\
320 \\
395\end{array}$ \\
\hline 2 & $\begin{array}{l}\text { Children's Hospitals: } \\
\text { Royal Hospital for Sick Children, Glasgow } \\
\text { Royal Hospital for Sick Children, Edinburgh } \\
\text { Royal Aberdeen Children's Hospital } \\
\text { Seafield Children's Hospital, Ayr }\end{array}$ & $\begin{array}{l}2 \\
2 \\
2 \\
2\end{array}$ & $\begin{array}{r}110 \\
127 \\
158 \\
24\end{array}$ \\
\hline $3 a$ & $\begin{array}{l}\text { Others-within } 30 \text { miles of neurosurgical unit: } \\
\text { Bangour General Hospital, Broxburn } \\
\text { Crosshouse Hospital, Kilmarnock } \\
\text { Dunfermline and West Fife Hospital, Dunfermline } \\
\text { Falkirk and District Royal Infirmary, Falkirk } \\
\text { Inverclyde Royal Hospital, Greenock } \\
\text { Monklands District General Hospital, Airdrie } \\
\text { Roodlands General Hospital, Haddington } \\
\text { Royal Alexandra Infirmary, Paisley } \\
\text { Victoria Hospital, Kirkcaldy }\end{array}$ & $\begin{array}{l}6 \\
6 \\
6 \\
6 \\
6 \\
6 \\
6 \\
6 \\
6\end{array}$ & $\begin{array}{r}253 \\
294 \\
223 \\
247 \\
221 \\
481 \\
71 \\
318 \\
259\end{array}$ \\
\hline $3 b$ & $\begin{array}{l}\text { Others-more than } 30 \text { miles from neurosurgical unit: } \\
\text { Ayr County Hospital, Ayr } \\
\text { Belford Hospital, Fort William } \\
\text { Dumfries and Galloway Royal Infirmary } \\
\text { Raigmore Hospital, Inverness }\end{array}$ & $\begin{array}{l}3 \\
3 \\
3 \\
3\end{array}$ & $\begin{array}{l}90 \\
29 \\
53 \\
55\end{array}$ \\
\hline
\end{tabular}

use in the department, but additional items specific to head injury were added for the purposes of this study. It was considered that the data from this hospital would be of high quality, but might not be representative of Scottish hospitals in general. Comparing the two populations was considered useful as a check on the validity of each data set.

DEFINITION OF A HEAD INJURY

This was any injury to the scalp, including swelling, abrasion or contusion as well as laceration; or a well authenticated history of a blow to the head; or any patient in whom a skull $x$ ray was performed immediately following trauma, and patients who had clinical evidence of fracture at the base of the skull. Patients with abrasions, lacerations or fractures limited to the face or facial skeleton were excluded, as were those with foreign bodies in the nose, ears or eyes. Birth injuries were excluded.

\section{Results}

DEMOGRAPHY AND CAUSES

Age and sex distribution was similar in the three surveys (table II), with children accounting for $40-51 \%$ of head injured attenders. Male predominance was slightly less for children as a whole than for adults, but of the youngest children only $58-63 \%$ were boys; $77-82 \%$ of 12-14 year olds were male, a greater proportion than in adults.
The causes of injury differed significantly in adults and children (table III). A fall accounted for more than half the injuries in children but for only a third in adults; assaults were more common in adults. Road accidents were the cause of only a minority of these predominantly mild injuries, both in children and adults. Children who had road accidents were more often pedestrians or pedal cyclists; only $20 \%$ were vehicle occupants, compared with $58 \%$ of adults. Of accidents that were not on the road, half of those in children and almost a third in adults occurred within the home;

Table III Commonest causes for head injured attenders (Scotland 1985)

\begin{tabular}{|c|c|c|}
\hline & Children & Adults \\
\hline $\begin{array}{l}\text { For all cases: } \\
\text { n } \\
\text { Fall } \\
\text { Assaults } \\
\text { RTA }\end{array}$ & $\begin{array}{r}2118 \\
57^{\circ} \\
6^{\circ} \\
9^{\circ}{ }^{\circ}\end{array}$ & $\begin{array}{r}3124 \\
333^{\prime \prime \prime} \\
290^{\prime \prime \prime \prime} \\
16^{\prime \prime \prime}\end{array}$ \\
\hline $\begin{array}{l}\text { Type of RTA: } \\
\text { n } \\
\text { Occupant } \\
\text { Pedestrian } \\
\text { Pedal cycle }\end{array}$ & $\begin{array}{l}183 \\
20^{\circ} \\
42^{\circ}{ }^{\circ} \\
32^{\circ}{ }^{\circ}\end{array}$ & $\begin{array}{l}470 \\
58^{\prime \prime} \\
23^{\circ}, \\
9^{\prime \prime \prime} \\
{ }^{\circ},\end{array}$ \\
\hline $\begin{array}{l}\text { Place of non-RTA }{ }^{1} \text { : } \\
\text { n } \\
\text { Home } \\
\text { Street } \\
\text { School/work }\end{array}$ & $\begin{array}{r}1162 \\
52^{\circ} \\
13^{\circ} \\
13^{\circ}{ }^{\circ} \\
{ }^{\circ}\end{array}$ & $\begin{array}{r}1477 \\
29^{\circ}{ }^{\circ} \\
29^{\circ} \\
17^{\circ}{ }^{\circ}\end{array}$ \\
\hline
\end{tabular}

RTA = road traffic accident

Place recorded in only $58^{\circ}$, of non-RTA cases

Differences in distribution between adults and children significant for each table $(p<0.001)$

less than one in six occurred at work or school. Even fewer were associated with sport, in an organised sense. If recreational activities in general are included, the proportion was greater, because a number of falls occur during such activities.

EVIDENCE OF BRAIN DAMAGE (table IV)

In the Scotland wide survey, which was based on retrospective inspection of routine records, only one per cent of children compared with five percent of adults had altered consciousness by the time they arrived at accident and emergency departments after recent head injury. In the prospective Monklands study the Glasgow Coma Scale was recorded on arrival, and in that hospital impaired consciousness was recorded as often in children as in adults. Some of these children were probably only temporarily drowsy or asleep, because the admission rate was no greater in Monklands than in the Scottish survey.

Some patients who were judged fully conscious on arrival had evidence of having had impairment of consciousness immediately after the injury.
Table II Age/Sex distribution in three surveys of $A / E$ attenders

\begin{tabular}{|c|c|c|c|c|c|c|c|c|c|}
\hline & \multicolumn{3}{|c|}{ Scotland 1974} & \multicolumn{3}{|c|}{ Scotland 1985} & \multicolumn{3}{|c|}{$\begin{array}{l}\text { Monklands } \\
\text { Hospital } 1984\end{array}$} \\
\hline & $\mathbf{n}$ & $\begin{array}{l}\text { \% in } \\
\text { age } \\
\text { group }\end{array}$ & $\begin{array}{l}\% \\
\text { male }\end{array}$ & $\mathbf{n}$ & $\begin{array}{l}\text { \%in } \\
\text { age } \\
\text { group }\end{array}$ & $\begin{array}{l}\% \\
\text { male }\end{array}$ & $\mathbf{n}$ & $\begin{array}{l}{ }_{n} \text { in } \\
\text { age } \\
\text { group }\end{array}$ & male \\
\hline $\begin{array}{l}\text { Child } \\
\text { Adult } \\
\text { All }\end{array}$ & $\begin{array}{l}1515 \\
2041 \\
3556\end{array}$ & $\begin{array}{l}43 \\
57\end{array}$ & $\begin{array}{l}67 \\
72 \\
70\end{array}$ & $\begin{array}{l}2118 \\
3157 \\
5275\end{array}$ & $\begin{array}{l}40 \\
60\end{array}$ & $\begin{array}{l}68 \\
71 \\
70\end{array}$ & $\begin{array}{l}1720 \\
1651 \\
3371\end{array}$ & $\begin{array}{l}51 \\
49\end{array}$ & $\begin{array}{l}65 \\
72 \\
67\end{array}$ \\
\hline $\begin{array}{l}<5 \mathrm{yr} \\
5-11 \mathrm{yr} \\
12-14 \mathrm{yr}\end{array}$ & $\begin{array}{l}576 \\
742 \\
197\end{array}$ & $\begin{array}{l}38 \\
49 \\
13\end{array}$ & $\begin{array}{l}58 \\
70 \\
82\end{array}$ & $\begin{array}{l}953 \\
868 \\
297\end{array}$ & $\begin{array}{l}45 \\
41 \\
14\end{array}$ & $\begin{array}{l}63 \\
72 \\
77\end{array}$ & $\begin{array}{l}799 \\
698 \\
223\end{array}$ & $\begin{array}{l}46 \\
41 \\
13\end{array}$ & $\begin{array}{l}58 \\
70 \\
78\end{array}$ \\
\hline
\end{tabular}


Table IV Frequency of altered consciousness in attenders.

\begin{tabular}{|c|c|c|c|c|}
\hline & \multicolumn{2}{|l|}{$\begin{array}{l}\text { Scotland } \\
1985\end{array}$} & \multicolumn{2}{|l|}{$\begin{array}{l}\text { Monklands } \\
1984\end{array}$} \\
\hline & $\begin{array}{l}\text { Children } \\
(n=2118)\end{array}$ & $\begin{array}{l}\text { Adults } \\
(\mathrm{n}=3124)\end{array}$ & $\begin{array}{l}\text { Children } \\
(\mathbf{n}=1720)\end{array}$ & $\begin{array}{l}\text { Adults } \\
(\mathrm{n}=1651)\end{array}$ \\
\hline No evidence of brain damage & $93 \%$ & $77 \%$ & $89^{\circ}$ o & $85 \%$ \\
\hline $\begin{array}{l}\text { History of altered consciousness } \\
\text { now recovered }\end{array}$ & $6 \%$ & $18 \%$ & $4 \%$ & $11 \%$ \\
\hline $\begin{array}{l}\text { Still altered consciousness at } \\
\text { A/E dept }\end{array}$ & $1 \%$ & $5 \%$ & $7 \%$ & $6 \%$ \\
\hline $\begin{array}{l}\text { Difference in distribution between } \\
\text { children and adults }\end{array}$ & $\mathrm{p}<0.00$ & 07 & $p<0.00$ & 07 \\
\hline
\end{tabular}

$\mathrm{A} / \mathrm{E}=$ accident and emergency

Either witnesses had reported this, or the patients were amnesic for the accident and a brief period after it. More adults than children were in this category, perhaps because it is easier to elicit an account of amnesia from adults. Other evidence of brain damage, such as a fit or focal neurological signs, rarely occurred in patients who did not also have evidence of altered consciousness.

\section{OTHER FEATURES}

Various reasons accounted for the attendance of a large number of patients who had no evidence of brain damage, and for regarding them as head injured. A scalp laceration was a feature of about half of both children and adults in the Scottish survey, and of more than a third in Monklands (table V). A laceration was less frequent in patients who had evidence of brain damage, in whom it was twice as common in adults as in children; as many children as adults without brain damage had a scalp laceration. Most other patients without brain damage either had a history of a fall or a blow to the head followed by headaches and/or vomiting; or they had recently ingested alcohol, which made the history uncertain or the state of consciousness difficult to assess. Recent alcohol intake was noted in a quarter of adult attenders, but in a third of those who had fallen, and in $38 \%$ of those who had been assaulted; only $11 \%$ of road accident victims had evidence of recent alcohol intake. Headache was more commonly complained of by adults (14-20\% v 8-10\%), and vomiting more often observed in children $(10 \% v 4-6 \%)$. However, only $15-22 \%$ of both children and adults complained of either of these features.

\section{POPULATION BASED RATES FOR ATTENDANCE} AFTER HEAD INJURY

Data are available for all new attenders at the hospitals in each of the 15 health board areas in Scotland, and the population served by each area can be derived from the Registrar General's figures. The survey of head injuries indicated the proportion of new attenders that were head injuries in each area. By extrapolation, the rates for Scotland as a whole were calculated. A similar method had been used to calculate rates for 1974 for limited subsets, and where comparison is possible the rates are similar (table VI). More detailed analysis was possible for 1985, in particular for adults and children of each sex, and by the three main causes (table VIIa, fig 1), and separately for those who had evidence of brain damage (table VIIb, fig 2).

For all causes together, the rates for children of both sexes were more than twice those for adults; for falls there was a fourfold difference in favour of children, whilst for road accidents there was little difference between children and adults. The attendance rates for those with evidence of brain damage were not only much lower, but the differences in rates between children and adults were no longer striking, except for assaults (table VIIb, fig 2). For all causes combined, the incidence of attenders with brain damage both for adults as a whole and for adult males was higher than it was for children.

Table VI New attenders at Scottish hospitals with head injuries-comparison of rates per 100000 population in 1974 and 1985

\begin{tabular}{lcc}
\hline & 1974 (Ref 7$)$ & 1985 \\
\hline All & 1778 & 1967 \\
Males & 2591 & 2832 \\
Females & 1024 & 1158 \\
Children & 3017 & 4011 \\
Road & 314 & 364 \\
Assault & 244 & 230 \\
\hline
\end{tabular}

SKULL X RAY AND ADMISSION TO HOSPITAL $\mathrm{X}$ rays were less often done in children $\left(58^{\circ}{ }_{0}\right)$ than in adults $(70 \%)$ in the Scottish survey; but in Monklands $80 \%$ of both age groups had a skull $x$ ray (table VIII). The lowest $x$ ray rates were in patients with scalp lacerations, especially children. Patients with no evidence of brain damage less often had $x$ rays in Scotland as a whole, but in Monklands this distinction was not seen. $\mathrm{X}$ ray was more often done when there had been headache and/or vomiting. A fracture was found in $2-3 \%$ of both children and adults who had $x$ rays.

Admission to hospital was twice as common in adults $(18-23 \%)$ as in children $\left(10-11^{\circ}{ }_{0}\right)$. Of patients without any evidence of brain damage, only seven percent of children and $12^{\circ}{ }_{0}$ of adults were admitted, compared with $61^{\circ}{ }_{0}$ and $58^{\circ}$ o respectively of those with brain damage. However, of those with consciousness still impaired on arrival at hospital, $25^{\circ}{ }_{0}$ of children and $16 \%$ of adults were sent home. Since the survey of 1974 and the publication of guidelines for the management of adults, the proportion of both children and adults who have $x$ ray
Table $V$ Frequency of scalp laceration in attenders.

\begin{tabular}{|c|c|c|c|c|c|c|}
\hline & \multicolumn{2}{|c|}{ Scotland 1985} & \multirow[b]{2}{*}{$\dot{\mathbf{p}}$} & \multicolumn{2}{|c|}{ Monklands 1984} & \multirow[b]{2}{*}{$\dot{\mathbf{p}}$} \\
\hline & $\begin{array}{l}\text { Children } \\
(\mathrm{n}=2118)\end{array}$ & $\begin{array}{l}\text { Adults } \\
(\mathrm{n}=3124)\end{array}$ & & $\begin{array}{l}\text { Children } \\
(n=1720)\end{array}$ & $\begin{array}{l}\text { Adults } \\
(\mathrm{n}=1651)\end{array}$ & \\
\hline $\begin{array}{l}\text { In all patients } \\
\text { In patients without brain damage } \\
\text { In patients with brain damage }\end{array}$ & $\begin{array}{l}48^{\circ} \\
48^{\circ} \\
14^{\circ} \circ\end{array}$ & $\begin{array}{l}50^{\circ} \\
52^{\circ}{ }^{\circ} \\
32^{\circ}{ }_{\circ}^{\circ}\end{array}$ & $\begin{array}{l}\text { NS } \\
<0.001 \\
<0.001\end{array}$ & $\begin{array}{l}36^{\circ} \circ \\
38^{\circ} " \\
15^{\circ} "\end{array}$ & $\begin{array}{l}38 " \prime \\
39{ }^{\prime \prime \prime} \\
33^{\prime \prime \prime}\end{array}$ & $\begin{array}{l}\text { NS } \\
\text { NS } \\
<0.001\end{array}$ \\
\hline
\end{tabular}


Table VII Attendance rates at accident and emergency, per 100000 population per year, by cause

\begin{tabular}{|c|c|c|c|}
\hline & \multicolumn{3}{|c|}{ Scotland 1985} \\
\hline & Children & Adults & All \\
\hline & \multicolumn{3}{|c|}{ (a) All attenders after head injury } \\
\hline $\begin{array}{l}\text { All } \\
\text { Males } \\
\text { Females }\end{array}$ & $\begin{array}{l}4011 \\
5340 \\
2613\end{array}$ & $\begin{array}{r}1473 \\
2180 \\
831\end{array}$ & $\begin{array}{l}1967 \\
2832 \\
1158\end{array}$ \\
\hline $\begin{array}{l}\text { Falls } \\
\text { All } \\
\text { Males } \\
\text { Females }\end{array}$ & $\begin{array}{l}2280 \\
2924 \\
1603\end{array}$ & $\begin{array}{l}459 \\
544 \\
381\end{array}$ & $\begin{array}{r}813 \\
1035 \\
605\end{array}$ \\
\hline $\begin{array}{l}\text { Assaults } \\
\quad \text { All } \\
\text { Males } \\
\text { Females }\end{array}$ & $\begin{array}{r}230 \\
350 \\
99\end{array}$ & $\begin{array}{l}399 \\
677 \\
147\end{array}$ & $\begin{array}{l}366 \\
610 \\
138\end{array}$ \\
\hline $\begin{array}{l}\text { RTA } \\
\text { All } \\
\text { Males } \\
\text { Females }\end{array}$ & $\begin{array}{l}364 \\
486 \\
235\end{array}$ & $\begin{array}{l}222 \\
306 \\
144\end{array}$ & $\begin{array}{l}249 \\
343 \\
161\end{array}$ \\
\hline
\end{tabular}

\begin{tabular}{|c|c|c|c|}
\hline \multicolumn{4}{|c|}{ (b) Attenders with evidence of brain damage 1} \\
\hline All causes & & & \\
\hline $\begin{array}{l}\text { All } \\
\text { Males }\end{array}$ & $\begin{array}{l}290 \\
305\end{array}$ & $\begin{array}{l}341 \\
537\end{array}$ & $\begin{array}{l}331 \\
508\end{array}$ \\
\hline Females & 180 & 163 & 166 \\
\hline \multicolumn{4}{|l|}{ Falls } \\
\hline All & 130 & & 120 \\
\hline Males & 165 & 168 & 167 \\
\hline Females & 94 & 73 & 77 \\
\hline \multicolumn{4}{|l|}{ Assaults } \\
\hline & 6 & 147 & \\
\hline & 8 & 171 & 137 \\
\hline Females & 4 & 26 & 22 \\
\hline \multicolumn{4}{|l|}{ RTA } \\
\hline All & & & \\
\hline Males & 141 & 77 & 112 \\
\hline Females & 55 & 39 & 42 \\
\hline
\end{tabular}

${ }^{1}$ Brain damage $=$ any evidence of altered consciousness either before or after reaching hospital, or neurological signs

examinations has increased; but there has been a reduction in the admission rate, which is more significant for children.

\section{Discussion}

While data are routinely collected on deaths and on hospital discharges (or admissions), no country appears to keep diagnostic records on attenders at emergency departments who are sent home. Almost all the epidemiological studies of head injuries published during the last decade in the USA and Australia have been limited to patients admitted to hospital, some of them including also deaths at the scene. Some surveys have been limited to children, others to adults; those that include both have only indicated the age distribution, without separately analysing the features of the two age groups.

Table VIII Frequency of skull $x$ ray in patients with different features

\begin{tabular}{|c|c|c|c|c|}
\hline \multirow[b]{3}{*}{ In all cases } & \multicolumn{2}{|c|}{ Scotland 1985} & \multicolumn{2}{|c|}{ Monklands 1984} \\
\hline & $\begin{array}{l}\text { Children } \\
(n=2118)\end{array}$ & $\begin{array}{l}\text { Adults } \\
(\mathrm{n}=3124)\end{array}$ & $\begin{array}{l}\text { Children } \\
(n=1720)\end{array}$ & $\begin{array}{l}\text { Adults } \\
(n=1651)\end{array}$ \\
\hline & $58 \%$ & $70^{\circ} \dagger<0.001$ & $80^{\circ}$ & $81_{\circ}^{\circ}$ \\
\hline $\begin{array}{l}\text { With scalp laceration } \\
\text { No laceration }\end{array}$ & $\begin{array}{l}40 \% \\
73 \% \%\end{array}$ & $\begin{array}{l}60 \% \\
79 \% \%\end{array}$ & $\begin{array}{l}64^{\circ}{ }^{\circ} \\
89^{\circ}{ }^{\circ} \ddagger\end{array}$ & $\begin{array}{l}73^{\circ} \% \\
86^{\circ}{ }_{\circ} \ddagger\end{array}$ \\
\hline $\begin{array}{l}\text { No evidence of brain damage } \\
\text { With brain damage }\end{array}$ & $\begin{array}{l}55^{\circ} \% \\
88^{\circ} \%\end{array}$ & $\begin{array}{l}64 \% \\
90^{\circ} \%\end{array}$ & $\begin{array}{l}80^{\circ}{ }^{\circ} \\
83^{\circ} \mathrm{NS}^{1}\end{array}$ & $\begin{array}{l}80^{\circ} \\
86^{\circ} \%\end{array}$ \\
\hline $\begin{array}{l}\text { Headache or vomiting } \\
\text { Neither }\end{array}$ & $\begin{array}{l}83^{\circ} \circ \\
53^{\circ} \circ\end{array}$ & $\begin{array}{l}88^{\circ} \\
67^{\circ} \circ\end{array}$ & $\begin{array}{l}89^{\circ} \circ \\
79 \%\end{array}$ & $\begin{array}{l}88 \% \\
79 \% \%\end{array}$ \\
\hline
\end{tabular}

$\mp \mathrm{p}<0.001 v$ laceration; $\S \mathrm{p}<0.001 v$ no evidence brain damage; $\uparrow \mathrm{p}<0.001 v$ headache/ yomiting; $\dagger \mathrm{p}<0.001$ adults $v$ children

Yomall number of children with brain damage

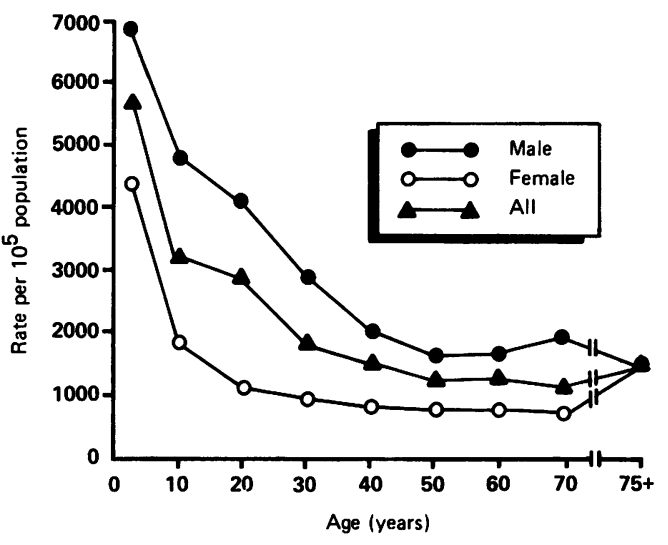

Figure 1 Annual incidence of attendance-all head injuries. (Scottish A/E Departments, 1985)

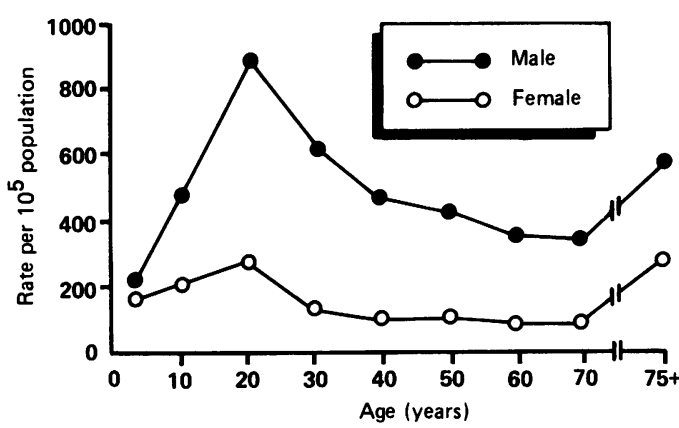

Figure 2 Annual incidence of attendance with evidence of brain damage. (Scottish A/E Departments, 1985)

The two previous Scottish studies showed that there were striking differences in the ages and the distribution of causes between head injuries of varying severity. ${ }^{5}$ Children made up more than $40 \%$ of those in accident/emergency departments, a third of those in wards of first admission, a fifth of severe injuries, but only about a tenth of fatal injuries. By contrast, road accidents were progressively more common as the severity of injury increased. The present study shows that, in the mainly mild injuries that predominate in accident departments, the causes differ strikingly between children and adults. Road accidents were an unusual cause in children, and in them most were pedestrians and pedal cyclists. In this study all injuries to cyclists were assigned as road accidents, but there is good evidence from several countries that most children injured when riding a bike have fallen when off the road. 68

As evidence of brain damage we chose simple criteria that could be applied in emergency departments. By these measures only a small minority of attenders had suffered any brain damage, and even fewer children than adults. It is, however, difficult to deny that these patients have suffered a head injury, because many of them had a scalp laceration and some of them a fractured skull. Some American epidemiologists 910 have excluded such attenders from their calculations of incidence. They also discounted patients who were admitted but who did not have loss of consciousness or post-traumatic amnesia of a certain duration; this meant excluding some who had a skull fracture. The subset of head injuries to which their incidence rates apply is often defined as "brain injuries". It was to allow comparison 
between the Scottish incidence rates for attenders and those for admissions in parts of the USA that we calculated rates separately for all attenders, and for those with evidence of brain damage (by our definition). These are the first population based estimates of the frequency of head injuries presenting at accident departments, analysed by age, gender and cause of injury. They could be useful when planning services for the head injured. Indeed, it is the large number of mildly injured patients who arrive at accident/emergency departments, whether or not they have evidence of brain damage by some arbitrary definition, that constitute the major challenge not only to health care systems, but also to clinicians who have to decide which to investigate, to admit for observation or to send home.

There remains some controversy about the indications for skull $x$ ray, CT scan and admission for observation after mild head injury. We shall deal with these issues in subsequent reports that will analyse patients who were admitted, and relate these issues to the risk factors that have been calculated by us for the development of acute intracranial haematoma ${ }^{11}$. Here we record simply the frequency with which skull $x$ rays were done and the proportion of patients who were admitted, noting the differences in practice for children and adults. This is the first step towards the evolution of guidelines for the management of children, to set beside those already developed for adults.
This Scottish survey, and the analysis of data from both sources, was supported by a project grant from the Health Services Research Committee of the Chief Scientist's Office, Scottish Home and Health Department. Data collection at Monklands Hospital was made possible by a grant from the General Manager of the Lanarkshire Area Health Board (Mr Frank Clarke).

1 Strang I, MacMillan R, Jennett B. Head injuries in accident and emergency departments at Scottish hospitals. Injury and emergency depa

2 Jennett B, Murray A, MacMillan R, et al. Head injuries in Scottish hospitals. Lancet 1977; ii: 696-8.

3 Gorman DF. Were you knocked out? Yes, but I wasn't admitted. Arch Emerg Med 1985; 2: 127-9.

4 Group of Neurosurgeons. Guidelines for initial management after head injury in adults. Br Med $\mathcal{F} 1984 ; 288$ : 983-5.

5 Annegers JF, Grabow JD, Kurland LT, et al. The Annegers JF, Grabow JD, Kurland LT, et al. The
incidence, causes and secular trends of head trauma in Olmsted County, Minnesota. Neurology 1980; 30: 912-9.

6 Kraus JF, Black MA, Hessol N, et al. The incidence of acute brain injury and serious impairment in a defined population. Am f Epidemiol 1984; 119: 186-201.

7 Jennett B, Macmillan R. Epidemiology of head injury. $B r$ Med $\mathcal{f}$ 1981; 282: 101-4.

8 Friede AM, Azzara CV, Gallagher SS, et al. The epidemiology of injuries to bicycle riders. Pediatr Clin $N$ Am 1985; 32: 141-51.

9 Craft AW, Shaw DA, Cartlidge NEF. Bicycle injuries in children. Br Med F 1973; IV: 146-7.

10 Kraus JD, Fife D, Conroy C. Incidence, severity and outcomes of brain injuries involving bicycles. Am $\mathcal{F}$ Public Health 1987; 77: 76-7.

11 Teasdale GM, Murray G, Anderson E, et al. Risks of acute traumatic intracranial haematoma in children and adults: implications for managing head injuries. $\mathrm{Br}$ Med $\mathcal{f} 1990$; 300: 363-7. 